BULLETIN Bulletin hispanique

HispaniQuE Université Michel de Montaigne Bordeaux

116-1 | 2014

Varia

\title{
Proyectos políticos y canon literario en los orígenes del comparatismo europeo
}

Összehasonlitó Irodalomtörténelmi Lapok (Acta Comparationis

Litterarum Universarum) y Crónica de los Cervantistas

Antoni Martí Monterde

\section{OpenEdition}

Journals

Edición electrónica

URL: http://journals.openedition.org/bulletinhispanique/3033

DOI: 10.4000/bulletinhispanique.3033

ISSN: 1775-3821

Editor

Presses universitaires de Bordeaux

Edición impresa

Fecha de publicación: 1 junio 2014

Paginación: 219-246

ISBN: 978-2-86781-931-5

ISSN: 0007-4640

Referencia electrónica

Antoni Martí Monterde, « Proyectos políticos y canon literario en los orígenes del comparatismo europeo », Bulletin hispanique [En línea], 116-1 | 2014, Publicado el 01 junio 2017, consultado el 26 mayo 2020. URL : http://journals.openedition.org/bulletinhispanique/3033 ; DOI : https://doi.org/ 10.4000/bulletinhispanique.3033 


\title{
Proyectos políticos y canon literario en los orígenes del comparatismo europeo
}

\author{
Összehasonlitó Irodalomtörténelmi Lapok \\ (Acta Comparationis Litterarum Universarum) \\ y Crónica de los Cervantistas
}

\section{Antoni Martí Monterde \\ Universitat de Barcelona}

Le propos de cet article est de traiter d'un épisode inconnu de l'histoire de la Littérature Comparée en Europe, la relation entre la première revue de la discipline (Acta Comparationis Litterarum Universarum), fondée en 1877 par Hugo von Meltzl et la première revue monographique consacrée au cervantisme (Chronique des cervantistes), créée dès 1871 par Ramón León Máinez.

Mots clés: littérature comparée, Hugo von Meltzl, Ramón León Máinez, Weltliteratur, Miguel de Cervantes, littérature européenne.

Este artículo se propone recuperar un episodio desconocido del momento fundacional de la Literatura Comparada en Europa, la relación entre la primera revista de la disciplina (Acta Comparationis Litterarum Universarum), fundada por Hugo von Meltzl en 1877, y la primera revista monográfica dedicada al cervantismo (Crónica de los cervantistas), impulsada en 1871 por Ramón León Máinez.

Palabras clave: Literatura Comparada, Hugo von Meltzl, Ramón León Máinez, Weltliteratur, Miguel de Cervantes, literatura europea.

This essay aims at remembering a forgotten scene in early Comparative Literature in Europe: the collaboration between the first comparative review, "Acta Comparationis Litterarum Universarum", founded in 1877 by Hugo von Meltzl, and the first monographic periodical devoted to Miguel de Cervantes, "Crónica de los Cervantistas" founded in 1871 by Ramón León Máinez.

Keywords: Comparative Literature, Hugo von Meltzl, Ramón León Máinez, Weltliteratur, Miguel de Cervantes, European Literature. 
ك ugo von Meltzl de Lomnitz, junto a Samuel Brassai, fue el impulsor de la

1 primera revista de Literatura Comparada que existió en Europa, fundada en 1877, y que tendría poco más de una década de existencia: Összehasonlitó Irodalomtörténelmi Lapok, más conocida por su cabecera a partir de 1879: Acta Comparationis Litterarum Universarum, seguida del título en las lenguas del Dekaglotismus que su director propuso como manera de articular la Weltliteratur goethiana con la incipiente Literatura Comparada. Sin embargo, pese a ser de alusión recurrente en las sucesivas introducciones e historias de la Literatura Comparada, la obra de Meltzl es conocida en profundidad solamente por algunos especialistas centroeuropeos en historia del comparatismo ${ }^{1}$. El nombre de su director se alinea junto a otros nombres que, por otro lado, podríamos considerar desconocidos también solamente por especialistas -ciertamente, hay que ser un especialista en la historia del comparatismo para poder llegar a tropezar con ellos, casi por azar, y llegar a ser consciente de su invisibilidad. Pero la Literatura Comparada no habría llegado a ser lo que hoy es sin el trabajo oscuro y abnegado de Meltzl; y esos otros nombres de que se acompañó en su aventura comparatística, de su mano, también forman parte de la extraña, paradójica, por momentos casi estrambótica, pero siempre fascinante, prehistoria de la Literatura Comparada.

Durante toda su existencia la revista hacía constar, en lugar destacado de la portada, un listado de «Socii operis» entre los cuales destacan Emilio Teza, Frédéric Amiel y Frédéric Mistral, futuro Premio Nobel de literatura. En el momento de máxima expansión de la iniciativa de Meltzl, y hasta el momento de clausurarse en 1888, en aquel listado constan hasta tres colaboradores de Cádiz: Ramón León Máinez, Romualdo Álvarez Espino, y P. de Maza; uno de Màlaga, A[ntonio] L[uis] Carrión; y otro de Granada, B[las]. L[eoncio]. de Peñar. (sic) De todos ellos, Máinez es quien colabora con más frecuencia en la revista, y su nombre es asiduo en la sección de noticias bibliográficas. Esto resulta sumamente sorprendente, más si tenemos en cuenta que en la revista solamente había tres colaboradores de París (dos de ellos de apellido húngaro); no hay, por ejemplo, ningún colaborador de Madrid. El predominio es de alemanes y magyares, evidentemente, residentes a menudo en el extranjero (de los seis colaboradores londinenses, solamente dos tienen apellido inglés,...) Todo parece indicar que es el círculo de amistades en las ciudades donde había

1. Árpád Berczik, «Les débuts hongrois de l'histoire littéraire comparée», Acta Litteraria, n. 2, 1959; György Mihaly Vajda, «Essai d'une histoire de la littérature comparée en Hongrie», en Littérature hongroise, Littérature européenne, Budapest, Akademiai Kiadó, 1964, pp. 215-249; György Mihály Vajda, «Acta comparationis litterarum universarum», Yearbook of Comparative and General Literature, 14, 1965, pp. 37-45; Charles Ijac, "Une ancienne revue de littérature comparée, "Acta comparationis litterarum universarum" (1877-1888)», Revue de Littérature Comparée 14, 1934; 733-745; David Damrosch, «Rebirth of a Discipline: The Global Origins of Comparative Studies», Comparative Critical Studies 3, 1-2, 2006, pp. 91-112; David Damrosch, "Global regionalism», European Review, vol. 15, n. 1, 2007, pp. 135-143; Horst Fassel, (ed.), Hugo von Meltzl und die Anfange der Komparatistik, Stuttgart, Franz Steiner Verlag, 2005; Antoni Martí Monterde, Un somni europeu. Història intel-lectual de la Literatura Comparada, València, PUV, 2011, p. 309-326. 
estudiado Meltzl, o donde tenía algún contacto académico o literario, el que nutre las páginas de la revista. Sin embargo la conexión andaluza, especialmente la conexión gaditano-transilvana, resulta mucho menos clara. Por mucho que el diario barcelonés La Vanguardia la elogiase el 15 de septiembre de 1885 como muestra del «Periodismo Universal», destacándola entre los 1200 periódicos de Austria-Hungría como «revista de literatura comparada que cuenta con colaboradores del mundo entero", su difusión no pudo ser demasiado generalizada al sur de los Pirineos. Aunque durante un cierto tiempo se editase entre Claudiopoli i Londini, resulta inaudito que llegase hasta Cádiz una revista de la cual cuesta encontrar colecciones completas fuera de la biblioteca universitaria de Cluj-Napoca. Lo cual exige una pregunta de carácter casi más novelesco que histórico: ¿llegaron a conocerse Máinez y Meltzl?

Ramón León Máinez nació en Jérez de la Frontera el 18 de junio de 1846, su modesta familia se instaló en Cádiz siendo él muy niño. Seminarista en Cádiz entre 1863 y 1869, bajo la protección del presbítero José María León y Domínguez comenzó a colaborar en El Domingo, publicación de entretenimiento pero también de carácter doctrinal y evangelizador, donde Máinez alterna artículos de crítica literaria e historia religiosa con las tareas de redacción e imprenta. Según sus escasos estudiosos ${ }^{2}$, esta actividad encauzó un carácter que con 22 años ya combinaba erudición, espíritu hipercrítico, y cierta terquedad en sus posturas políticas, intelectuales y religiosas. Cuando abandonó el seminario, evolucionó hacia un ateismo militante y obrerista, publicando en 1880 Teresa de Jesús ante la critica, un duro ataque a la figura de Teresa de Ávila, dejando inéditos otros alegatos contra la religión cristiana. Evidentemente, había experimentado una profunda transvaloración de todos los valores. Colaboró en La Buenas Novelas como redactor y traductor; en 1871 llegó a ser durante un breve periodo director del Diario de Cádiz. Posteriormente, en 1876 dirigió el periódico conservador La Palma de Cádiz, para evolucionar nuevamente abrazando la causa republicana, como director de El Pueblo. Periódico Político y Literario, Defensor de las Clases Jornaleras. Desde 1901 hasta 1907 trabajó como secretario de Eduardo Benot, en Madrid, donde pasó también los últimos diez años de su vida en una situación de gran precariedad económica y aquejado de una grave enfermedad mental, hasta el punto que en 1915 se difundía una nota del comité organizador del tercer centenario de la muerte de Cervantes, llamando a una "Suscripción a favor del veterano cervantista D. Ramón León Máinez», que por lo que se puede apreciar en su redacción, no había sido debidamente atendida:

Seguramente habrá pasado inadvertido el suelto de nuestro cuaderno de Mayo en que abrimos esta suscripción, cuando los amadores de Cervantes, a quienes consta lo mucho

2. Para la biografía de Máinez, en el contexto del cervantismo véase: Fernando Durán López, "El gran poema de la Humanidad", Ramón León Máinez y la Vida de Cervantes», Ínsula, 727 728, julio-agosto de 2007, pp. 28-30; Yolanda Vallejo Márquez: «Aproximación al cervantismo decimonónico: el cervantismo gaditano», Draco, 5-6, 1993-1994, pp. 243-263; Manuel Ravina Martín: «Dos cartas inéditas de Patrocinio de Biedma y Ramón León Máinez», Boletín del Instituto de Estudios Gienenses, 190, 2005, pp. 653-672. 
que por su renombre y el de sus obras ha trabajado el Sr. Máinez, no se han apresurado a ofrecerle sus socorro, bien directamente, enviándolo a su esposa dońa Carmen Ballesteros (...) Rogamos a los diarios de mucha circulación que enteren a sus lectores de que el fundador de la antigua Crónica de los Cervantistas y excelente biógrafo de Cervantes se halla gravemente enfermo y sin recursos. Algo debemos todos a quien tan de veras trabajó largos años por la cultura nacional ${ }^{3}$.

Esta nota casi ponía punto y final a la trayectoria vital de Máinez, que murió poco después, en 1917, al tiempo que subrayaba su otra línea biográfica fundamental: el cervantismo.

Se escribe cervantista para referirse a su condición, y no estudioso de Cervantes, o biógrafo de Cervantes, o filólogo -que no lo fue en el sentido estricto de la palabra- especializado en la obra de Cervantes, porque su relación con el autor del Quijote tiene mucho más de publicística que de crítica. De hecho, el Cervantismo no es sino el movimiento lógico que sucedió al Quijotismo, en la historia de la literatura española del siglo XIX; Máinez, así pues, supone un punto de inflexión, e incluso de saturación, en el desplazamiento de la figura del personaje a la figura del autor como construcción del mito historiográfico -desplazamiento que se había iniciado, sobre fundamentos mucho más sólidos, con la Vida de Miguel de Cervantes Saavedra (1837), de Gregorio Mayans, que acompañaba la edición de Londres-, combinando el trabajo biográfico, la edición y la difusión más o menos periodística en relación a la constitución del campo literario español del período finisecular que todavía estaba gestando su propia idea de literatura nacional. Con todo, este carácter apologético y nacionalista no es extraordinario en el último tercio del siglo XIX; lo excepcional en Máinez no es su falta de consistencia crítica, ni su posición, sino su caracterización de lo que Cervantes había de suponer como motor de una regeneración española en clave internacional, y la manera de impulsar ese propósito. Tal como puede leerse en las conclusiones de su biografía de Cervantes:

Sólo conmemorando el aniversario de su muerte en todos los pueblos cultos del mundo, levantándole en España un monumento majestuoso y digno de su sabiduría, constituyendo en cada ciudad de ella una Sociedad dedicada a propagar sus producciones y enaltecer su memoria, y declarando Fiesta NACIONAL el 23 de abril, se responderá, en lo posible, a lo que sus merecimientos reclaman, su gloria pide y el agradecimiento patrio y universal perpetúa. ${ }^{4}$

Tras Cervantes y los críticos, (1871), en que planteaba la necesidad de revisar la apreciación del autor de Don Quijote de la Mancha, su trabajo fundamental fue una monumental -en todos los sentidos-Vida de Cervantes, publicada en Cádiz en 1876; complemento de la edición del Quijote que él mismo realizó, también con notable voluntad polémica. Su reto fue, con esta edición realizada en Cádiz en 1877-1879, «restituir la pureza primitiva del texto» de 16051615, respondiendo a las 1633 notas con que Juan Eugenio Hartzensbusch complementó la edición fototipográfica de Barcelona (1873-1879), de la

3. «Un cervantista en la miseria», $A B C, 2$ de noviembre de 1915, p. 19.

4. Ramón León Máinez: Vida de Cervantes, Cádiz, Tipografía La Mercantil, 1876; vol. I. (sic., no existe el volumen II), p. 362-363. 
de Juan de la Cuesta, «rechazando las más de las variantes aceptadas por la Academia, y por ello sancionadas y legalizadas, como las muchas innecesarias que han propuesto algunos críticos modernos». ${ }^{5}$ Pero, más allá de la discusión sobre crítica textual, es la textura de su biografía, y su complemento publicista, lo que más nos interesa, que impregna sus anotaciones y que proseguirá con Miguel de Cervantes. El proceso de Valladolid (1886), y Cervantes y su época, (1901). Pero fundamentalmente con la creación de la primera revista dedicada monográficamente al cervantismo: Crónica de los cervantistas.

Cabe señalar en este punto que uno de sus protectores fue Mariano Pardo de Figueroa, autor de las Epistolas Droapianas (1868) en que un ficticio Mr. Droap (Pardo) se dirige a otro estudioso cervantino, todavía más inventado, el alemán Dr. E. W. Thebussem (embuste), propietario del castillo de Tirmenth (mentir), por cuya cuenta Droap se encuentra en España buscando ediciones cervantinas para su colección. Quizá fuese Pardo de Figueroa el contacto directo o indirecto de Máinez con Meltzl, ya que el introductor de la tarjeta postal en Espańa, con contactos en la realeza y el gobierno, tenía por tanto cierto acceso a medios diplomáticos o al menos internacionales, y -también cervantista empedernido, aunque sobretodo irónico-ya se propuso en su momento publicar un periódico trimestral, Crónica de la Sociedad de Cervantes. Este proyecto, impulsado de manera simultánea a la redacción de la Vida de Cervantes y la organización de diversas fiestas conmemorativas de su figura, será realizado finalmente por Máinez: el 7 de octubre de 1871 aparece Crónica de los Cervantistas, con la complicidad de un impresor (Tipografía la Mercantil), donde vería la luz su edición. La revista tendrá una vida efímera, apareciendo con irregularidad hasta 1879, aunque tendrá una segunda etapa, ya en Madrid, entre 1904-1906, con motivo del centenario de la publicación del Quijote.

Tanto en el tono como en los contenidos, Crónica de los Cervantistas resulta fundamentalmente una exaltada celebración casi permanente de la figura cervantina, intensificada en los números de cada mes de abril, salpicada de poemas dedicados a su grandeza, combinada con notas bibliográficas y con la publicación de entregas sucesivas de los trabajos biográficos de Máinez. Por un lado, Crónica de los Cervantistas se define como el órgano de difusión de estudios que hasta entonces faltaba, «eco fiel de los cervantistas, ora nacionales, ora extranjeros»:

El periódico [que] viene a llenar ese vacío que se notaba en la república de las letras. La Crónica de los Cervantistas procurará ser el fiel eco de todos los admiradores de Cervantes, sin distinción de opinión o de idea, de patria o de nombre: no será órgano literario de determinados escritores, sino que los escuchará a todos, insertará trabajos de todos, y aun se debatirán en ella las cuestiones cervantinas más delicadas, para producir la luz, llevar al ánimo el convencimiento, aclarar las dudas, y abrir ancho sendero a la propagación de las ideas. ${ }^{6}$

5. Cit. en Ravina, op. cit., p. 661.

6. S.f. [R. L. Máinez]: «Objeto de esta publicación», Crónica de los Cervantistas I, n. 1, 7 de octubre de 1871 , p. 1. 
No cabe duda de que se trata de una declaración de principios plenamente encomiable, aunque en ella los trabajos se caractericen con los adjetivos de «eruditos, castizos, inéditos, originales, elegantes y escogidos.» ${ }^{7} \mathrm{~A}$ pesar de que el casticismo pueda parecer insuperable, aplicado a la erudición, en el número de 15 de julio de 1878, en una nota firmada por Juan de V. Portela, se caracterizaba al conjunto de los redactores en términos todavía más elocuentes, casi pasándose del casticismo al catecismo:

Somos cervantistas, es decir, misioneros de Cervantes; venimos a continuar su obra social; no tenemos dote para proseguir su obra literaria, y por eso no escribiremos ni sus "Novelas Ejemplares" ni su grandioso "Quijote"; pero en la continuación de su apostolado, siempre trabajaremos.

No nos llamamos Cervantistas por soberbia; no es que creamos que nuestras plumas valgan más que otras; así como nos llamamos cristianos por tener la fe de Cristo y no sus virtudes, nos decimos cervantistas por tener su pensamiento. ${ }^{8}$

Esta misión se desea y se proclama de alcance internacional, y por tanto, no es de extrañar que su principal impulsor intente aprovechar cualquier resquicio o contacto para hacer su proselitismo cervantino, puesto que toda acción de construcción de un prestigio en el extranjero contribuye -a veces, sobretodo a consolidar el prestigio dentro del campo literario nacional. En el caso que nos ocupa, incluso a realizar un acto de carácter patriótico. Escribe Romualdo Álvarez Espino en uno de los últimos números de la revista:

No, no es el afán de exhibición el que lleva a los hombres ante la tumba del gran Cervantes; es el amor patrio, es el deseo de una noble vendicta, es el deber de un siglo de lavar las manchas de otro: es la ley de las recompensaciones con que se significa la justicia providencia; y es, cuando menos, el deseo legítimo de manifestarse poeta al par que noble defensor de la literatura patria. ${ }^{?}$

A partir de estas bases, que ya no son sino una exagerada demostración de lo que Fernando Durán López ha llamado una «religión laica nacional $»^{10}$, no es de extrañar que autor y personaje se sitúen en un mismo plano, puesto que su objetivo no es crítico, sino apologético hasta lo patológico. Como ha señalado el mismo Durán, la biografía de Cervantes escrita por Máinez constantemente disfraza de rigor documental lo que no es sino una confusión continua entre Cervantes y su personaje, don Quijote, sintetizándose una tercera imagen, el Cervantes de la biografía donde la falta de datos sobre el autor se suple con

\section{Ibidem, p. 2.}

8. Juan de V. Portela, «Los Misioneros de Cervantes», Crónica de los Cervantistas III, n. 2, 15 de julio de 1878, p. 43-44. Lo cual no impide que en las páginas de Crónica de los Cervantistas se desarrolle una polémica, entre el mismo Máinez y José María Sbarbi, sobre si Cervantes fue o no teólogo; véase Vallejo, op. cit., p. 250.

9. Romualdo Álvarez Espino, «Un modo raro de entender las cosas», Crónica de los Cervantistas III, n. 2, 1878, 15 de julio de 1878, p. 65.

10. Fernando Durán López, op. cit., p. 30. 
la caracterización de don Quijote como fuente, una tercera figura en la cual se depositan todos los valores, incluso conocimientos enciclopédicos, que permiten glorificar a Cervantes ${ }^{11}$. Miguel de Cervantes Saavedra, así pues, es Don Quijote -y no solamente un quijote- a efectos biográficos; pero, por supuesto, no tiene absolutamente nada de ningún otro de sus personajes, ninguno de ellos es tomado como fuente, y menos Sancho Panza. Todo ello no deja de ser un ejemplo del imaginacionalismo de las historias de la literatura en el siglo XIX, o, tal como lo plantean Eric Hobsbawn y Terence Ranger, se trata de una anécdota más de la Invención de la tradiciones ${ }^{12}$, en este caso española:

Con quien se identifica Don Quijote, a quien representa aquel gallardo carácter, de quien es vivo y acabado retrato, es de su historiador, de Cervantes. Éste, como el protagonista de su obra, sin miedo ni tacha, truena siempre contra todo lo malo y perjudicial; ama la rectitud, adora la verdad; y ni le intimidan los peligros, ni las asechanzas le abaten, ni las contrariedades le amilanan (...) Cervantes, como don Quijote, era un visionario, un loco, un hombre digno de compasión para la generación metalizada y positivista. ${ }^{13}$

Incluso podríamos añadir una cuarta figura surgida de tal planteamiento: el mismo Máinez - que indudablemente también intentaba construir su propio prestigio en el campo académico nacional, y que llegó a firmar diversos trabajos bajo el pseudónimo de El Bachiller Cervántico. Si Cervantes podía ser el historiador del Quijote, Máinez podía serlo de Cervantes, incluso de la misma manera. Aplicado estudiante, devoto erudito, prosélito incondicional, lleva esta identificación hasta donde le alcanzan las fuerzas.

Y las fuerzas le llevan hasta Transilvania.

No resultará fácil averiguar, si algún día se llega a saber, cómo cayó en manos de Máinez algún ejemplar de Összehasonlitó Irodalomtörténelmi Lapok, pero sí podemos documentar que conoció su existencia bastante pronto, ya que en el número de 30 de abril de 1877, la redacción acusa recibo del número de 7 de octubre de Crónica de los Cervantistas, así como de una carta de su «fundator y director», quien ya es incorporado en el número siguiente al listado de colaboradores situado bajo la cabecera de la revista. Así pues, la relación entre ambas revistas comenzó a iniciativa de Máinez, y se concreta con la inmediata colaboración del gaditano en las páginas de la revista austrohúngara.

Cuando Máinez está ultimando la publicación del tercer volumen de su edición del Quijote, tal como procedía también en sus propias publicaciones periódicas, avanza en la revista transilvana un "Comentario inédito del Quijote», publicado en dos entregas, donde se puede apreciar bastante de lo dicho. Mientras para don Quijote se reservan -lógicamente, por otro lado,

11. Ibidem. p. 29

12. Véase Eric J. Hobsbawn, Terence Ranger, (eds.), The Invention of Tradition, Cambridge, Press Syndicate of the University of Cambridge, 1983, esp. la ntroducción.

13. Ramón León Máinez, Vida de Cervantes, op. cit., p. 138. 
"personificación de la verdad, de la justicia, de la rectitud y de la perfección más grande», Sancho Panza, no es sino la «personificación en estos capítulos del más sórdido interés y del más grosero egoísmo», y de ese contraste en el que no existe ni la menor complementariedad, se desprende que:

el hombre íntegro, generoso, todo abnegación por sus semejantes, de quien es representación fidelísima Don Quijote, jamás se intimida ante las maquinaciones del mundo positivista: en esa lucha gigantesca que tiene que sostener contra las malas artes de todos, podrá quedar vencido, y quédalo efectivamente a la continua; mas al fin se le hace justicia, se reconocen sus altos designios, se subliman sus actos, y se circuye su nombre con la aureola de la gloria, en tanto nadie se acuerda, sino para compadecerlos, de cuantos se opusieron al trinfo de sus ideas y a la realización de sus propósitos generosos. ${ }^{14}$

La publicación de la primera parte de este comentario supone, además, la presentación de la revista de Meltzl a los lectores de Crónica de los Cervantistas, donde se recoge casi como un acontecimiento; lo cual, indirectamente, sirve para presentar entre el público de la revista la Literatura Comparada, antes incluso de las noticias vagas y difusas que pudieran tener a través del eco que se irá haciendo Marcelino Menéndez Pelayo de los trabajos de AbelFrançois Villemain y Manuel Milà i Fontanals, los tres bastante cuestionables como precedentes del moderno comparatismo, hacia el que ya se encamina decididamente Meltzl:

En la revista húngara que con el título de Zeitschrift für Vergleichende Litteraturse publica en Kolozsvár bajo la dirección de los insgnes Doctores Samuel Brassai y Hugo de Meltzl, se ha insertado últimamente un comentario inédito de El Quijote, trabajo original del director de CRónica de los Cervantistas. El periódico de Hungría está exclusivamente dedicado a la Historia de las literaturas comparadas, y es de suma importancia y utilidad para las personas doctas de todas las naciones cultas.

Jamás podremos agradecer bastante las atenciones con que nos ha favorecido y favorecen los propietarios de la Revista literaria que nos ocupa, y especialmente del Dr. Meltzl, quien no contento con invitarnos para que escribamos en unión de nuestros amigos en su periódico, dando a conocer en aquellas comarcas de Europa la literatura contemporánea española, nos ha puesto en relaciones gratísimas de amistad con muy distinguidos talentos de Prusia, Sajonia, Italia, Suiza, y otras naciones. ${ }^{15}$

Y, efectivamente, las colaboraciones de Ramón León Máinez en Összehasonlitó Irodalomtörténelmi Lapok, sin llegar a ser frecuentes ni regulares, no deben considerarse esporádicas, puesto que en el período en que ambas revistas se publican de manera simultánea -es decir, el bienio 1877-1879- además de las dos entregas de comentario cervantino, llega a publicar dos traducciones de Sándor Petöfi al castellano y una reseña de una obra de dialectología

14. Ramón León Máinez, "Comentario inédito del Quijote, I», Összehasonlitó Irodalomtörténelmi Lapok, X, 31 de mayo de 1877, pp. 188. En la transcripción de los textos se ha actualizado la ortografía y se ha corregido algún evidente error de transcripción. Texto completo en el apéndice documental.

15. Ramón León Máinez, «Noticias varias», Crónica de los Cervantistas, III, n. 1, 30 de junio de 1877 , p. 35. 
hispanoamericana de Félix C. y Sobrón, bajo el título «Los idiomas de América Latina». Además, el corpus de trabajos de Máinez se acompaña de otros textos de colaboradores andaluces cuya publicación seguramente gestionó él mismo. Por otro lado, Összehasonlitó Irodalomtörténelmi Lapok acusará recibo de los libros de Máinez, que hace llegar en correspondencia, y se hará eco de las actividades que, el mes de abril de cada año, organice su círculo cervantino.

Como contrapartida, el 20 de junio de 1877 aparece en las páginas de Crónica de los Cervantistas la siguiente efusiva invitación:

El Dr. Meltzl, catedrático de la Universidad de Kolozsvár, es uno de los más sinceros admiradores de Cervantes. (...) Enviamos al ilustre filólogo, crítico y admirador de la literatura española, Dr. Meltzl, nuestros más respetuosos recuerdos por las muchas atenciones con que nos distingue, y le rogamos no deje de remitirnos para la Crónica sus doctos trabajos, pues en su publicación tendremos honra y orgullo. ${ }^{16}$

En cuanto a las traducciones de Petöfi, cabe señalar que son consecuencia directa de ese primer momento de intercambio entre ambas revistas. La notícia de Máinez sobre Összehasonlitó Irodalomtörténelmi Lapok incluía un agradecimiento a Melztl fundamental para entender la reciprocidad de la relación:

Merced a su galantería hemos recibido un precioso libro suyo, publicado en Leipzig en 1871, que contiene traducidas al alemán muchas bellísimas y selectas composiciones líricas del gran poeta húngaro Petöfi. Si nosotros podemos ofrecer una traducción española de tan admirables poesías, veremos realizado uno de nuestros más nobles deseos, tributando de este modo un pequeño homenaje de nuestra admiración hacia el vate inmortal de Hungría y hacia su inteligente traductor. ${ }^{17}$

Quizá así quede más claro porqué Máinez se refiere siempre a la revista de su interlocutor según su cabecera en alemán, y no en húngaro. Máinez, que sabía alemán, realizá sus traducciones de Sándor Petöfi a partir de las versiones del mismo Meltzl, a quien expresa sus sensaciones al leer a su autor predilecto en una carta, publicada en el número xIII, de 15 de setembre de 1877, que incluía la traducción de «La Canción», y donde se anunciaban nuevas tentativas de versiones al castellano del autor predilecto de Meltzl, «el gran vate húngaro Petöfi», puesto que "Mientras más se estudian las poesías del poeta eminente de su país de V., más se acrecienta la admiración hacia su nombre preclaro y la veneración hacia su memoria. (...) Ahora estoy ocupado con la versión y composición en verso castellano de la magnífica inspiración titulada: $A z$ árveleány (Das verwaiste Mädchen) La huérfana. ...donde compiten los pensamientos sublimes[,] los tiernos sentimientos y las más patéticas pinturas con la expresión más sencilla y las frases más llanas y dulces». ${ }^{18}$ Efectivamente,

16. Id. p. 35-36

17. Ibidem.

18. Hugo von Meltzl, «Petöfiana, II. Petöfi in spanischer Sprache», Öszehasonlitó Irodalomtörténelmi Lapok, XIII, 15 de setembre de 1877, p. 273-274. 
«La huérfana» se publicaría en septiembre del mismo año, aunque en esta ocasión sin nota de presentación alguna, como una traducción más de la sección Petöfiana.

Al margen de documentar su presencia en páginas tan remotas, deben establecerse algunas hipótesis sobre por qué le interesó tanto a Ramón León Maínez Összehasonlitó Irodalomtörténelmi Lapok, revista fundada pocos años después de la suya. Puede afirmarse que Máinez encuentra en Meltzl un modelo, sensiblemente mejorado, de lo que él mismo pretendía desde hacía algunos años realizar con Cervantes, así como una oportunidad de realizarlo efectivamente. Meltzl retoma la afirmación goethiana de que la poesía es un acervo común a todos los hombres, y que aparece en todas partes y en todos los tiempos representada en centenares y centenares de hombres ${ }^{19}$; tanto como su preocupación por la posición de la propia literatura -la alemana y la suya personal- en la idea de Literatura Europea, y en la Weltliteratur. En lo que respecta a la lengua, es consciente de que Hungría representa, debido a la peculiar condición idiomática en el plurilingüismo europeo, la alteridad casi absoluta en el mismo centro de Europa. Cualquier relación entre la literatura húngara y la literatura europea parte de esta marcada diferencia que la aísla. Precisamente desde esta conciencia surge su iniciativa de un poliglotismo científico impulsado por la revista, que debiera tener consecuencias más allá de su mera función instrumental: estaba destinado a hacer posible un público húngaro que "no sabrá existir sin una cultura superior, políglota» ${ }^{20}$. Según Meltzl,

no podremos poner remedio al aislamiento de la poesía y de la literatura húngara si no nos procuramos puntos de contacto y de comparación tan frecuentemente como sea posible. (...) [Acta Comparationis Litterarum Universarum] no promoverá más que los puntos de contacto originales y directos, limitándose a la literatura propiamente dicha, que es el alma de los pueblos. (...) Con las publicaciones científicas escritas sobre nosotros y por nosotros solamente conseguiremos desanimar a los pueblos extranjeros. Una muchacha hace bien en esperar pretendiente. Nosotros no podemos poner remedio al aislamiento de la lengua y la poesía húngaras más que con nuestro principio políglota. ${ }^{21}$

Así pues, desde esta conciencia y haciendo de la necesidad virtud, la revista exhibirá en su cabecera esta condición: en el primer número aparece el título en húngaro; justo debajo, en caja más pequeña pero muy visible, en alemán -Zeitschrift für vergleichende Litteratur- y en francés -Journal d'Histoire des Littératures Comparées-; en tipografía aún más pequeña, y no sin alguna incorrección, en italiano -Periodico pella storia letteraria comparativa-, en

19. J. P. Eckermann, Conversaciones con Goethe; [Gespräche mit Goethe in den Letzen Jahren seines Lebens, (1836-1848)]; trad. cast. de Jaume Bofill y Ferro, Madrid, Iberia, 1946, 2 vols; vol. I. pág. 201-202.

20. [A szerkesztöseg (Editorial)] «Elöszó», Összehasonlitó Irodalomtörténelmi Lapok, I, 1, 1877. 1-2; trad. fr. fragmentaria en Berczik, Árpád: «Les débuts hongrois de l'histoire littéraire comparée», Acta Litteraria, n. 2, 1959, p. 226.

21. Ibidem. 
inglés $-A$ weekly paper for the comparison of history of literatures-, y castellano -Papel periódico por la comparación de las producciones literarias-; con alguna formulación mejorable, que con el paso del tiempo será corregida (el número del 15 de abril ya es un Journal de Littérature comparée; el del dia 30, Periódico para la Historia de las literaturas comparadas; el del 31 d'octubre, tras diversas probaturas, se consolida la fórmula Comparative literature journal). A estas lenguas se debe sumar todavía el holandés, el islandés, el sueco y el portugués; y, a partir de 1879 , hasta su clausura en 1888 , todo ello bajo la cabecera latina de referencia. Aunque con el tiempo se simplificaría esta enrevesada disposición tipográfica, los contenidos se mantienen fieles a este principio que Meltzl denomina poliglotismo o Dekaglotismus, a los cuales añade el latín (pero no el griego) en sus definiciones programáticas. La revista quiere ser, tal como lo formula en sus lemas, un «Acta Comparationis für Goethe'sche Weltlitteratur». La pequeña errata no resta valor al propósito.

Todo ello apuntando a lo que Meltzl considera una «Reforma literaria de Europa», en un importante artículo programático publicado en francés -normalmente lo hacía en húngaro o en alemán- entre otras razones por tratarse de un comentario del congreso literario celebrado en París, a cuyos asistentes pretendía como primeros interlocutores de su propuesta. Una propuesta que parte de la necesaria reforma de la idea de internacionalidad en una Europa que, en los años setenta, ha visto modificadas sus fronteras políticas de manera decisiva, pero que se intuye como no definitiva:

La internacionalidad utilitaria (pero no en el sentido vulgar) es una de las más interesantes e importantes tareas de nuestro tiempo; es la única posibilidad de elevar el nivel de las ideas, de relacionar las inteligencias. Los grandes pensamientos no son en absoluto privilegio de las grandes naciones; son el privilegio de los grandes corazones -y el gran corazón se extiende por todas partes, en todos los pueblos. ${ }^{22}$

Según su opinión, sería necesario que se constituyese e impulsase esa nueva internacionalidad primordialmente por la gente de letras, pero de una manera completamente diferente a como se habían establecido las relaciones entre política y literatura en el siglo XIX. De hecho, no sería posible esa reforma literaria de Europa sin una reforma de la Historia literaria:

la reforma de la historia literaria; una reforma largamente esperada y largamente aplazada, que solamente es posible a través de la aplicación extensiva del principio comparativo. Como muchos hombres de letras imparciales saben, la moderna historia literaria, tal como es practicada hoy por hoy, no es sino una ancilla historiae politicae, o una ancilla nationis, en el mejor de los casos una ancilla philologiae (en el sentido moderno del término. (...) No hay, en estos momentos, ninguna área del estudio literario, más saturada, poco atractiva $y$, sin embargo, frecuentada que la Historia literaria; y no hay ninguna que prometa menos. ${ }^{23}$

22. Hugo von Meltzl, «La réforme littéraire en Europe. Quelques observations à propos de l'ouverture du Congrès Littéraire International à Paris en juin 1878", Acta Comparationis Litterarum Universarum, n. xxxI, 1878, 42/682.

23. Hugo Meltzl de Lomnitz, "Vorläufuge aufgaben der vergleichende litteratur. I», Acta Comparationis Litterarum Universarum, Ix, 15 de maig de 1877, trad. cit., p. 57 
A su entender, el estudio de la literatura y las relaciones entre literaturas tendría que parecerse más al espíritu de las exposiciones universales y de los congresos literarios, y pasaría por la creación de un Instituto Literario Universal $o$ Comparativo $0^{24}$. Este organismo, para el cual llegó a redactar y publicar en ACLV un borrador de estatutos, sería la concreción definitiva del espíritu goethiano de la Weltliteratur, cuyo cincuentenario - de la idea y neologismo de Goethe, y de la muerte del autor- se conmemora en la revista con la voluntad claramente de retomar aquel ideal. Por ello propone su revista como un «lugar de encuentro para autores, traductores y filósofos de todas las naciones», con el ánimo de fundar la nueva disciplina en «el arte de la traducción, que solamente ha sido aceptado en su plena importancia a partir de Goethe -la consecuencia del cual es nada menos que la disciplina emergente del futuro: la Literatura Comparada. ${ }^{25}$ Este planteamiento operaba de manera dialéctica: tenia un doble horizonte, nacional-húngaro y weltliterario-europeo, tan profundamente intricado entre sí que ninguna conceptualización -por concreta o parcial que parezca-en lo que respecta a la propia literatura dejaba de tener sus consecuencias generales en la idea de literatura universal $-\mathrm{o}$ al menos europea-, y viceversa: toda reflexión sobre la idea de literatura europea o universal implicaba una redefinición de la propia literatura.

La manera de plantear la necesidad de romper el aislamiento lingüístico y de reformar la idea de público literario culto, dentro y fuera de Hungría, sin duda, interesó a Máinez, puesto que, no por cuestiones lingüísticas, la España del último tercio del siglo XIX no se encontraba menos aislada del resto de Europa. Pero Crónica de los Cervantistas no registra en ningún momento esa manera de romper el aislamiento; del modelo supranacional de Meltzl, al gaditano solamente le interesa el alcance de la difusión de la obra de Cervantes que les permite.

Ésta es precisamente la cuestión que pudo llamar la atención de Máinez: lo que guía la primera acción crítica de Meltzl, ya antes de emprender Összehasonlitó Irodalomtörténelmi Lapok, son sus estudios sobre Sándor Petöfi. Estos estudios tenían una naturaleza polémica: cuando Meltzl debuta como profesor universitario, al negarse su Universidad a una iniciativa suya para celebrar el cincuentenario del poeta, y cuando el responsable institucional de la negativa afirma en sus clases que se trata de un autor de segunda fila, Meltzl decide impartir un curso sobre su Petöfi, y realiza un conjunto de trabajos y traducciones. En uno de estos estudios afirma que Petöfi «da, de un sólo golpe, a la literatura húngara el horizonte de la literatura mundial». ${ }^{26}$ Parece como si, un vez escrita esta frase, Meltzl tomase el compromiso de demostrarla o, más bien, de convertirla en evidencia, en la realidad literaria de su país, y de hacerla igualmente obvia en el marco del ideal goethiano. Como subraya Berczik, es com si hubiese constatado que

24. Hugo von Meltlz, «La réforme littéraire en Europe», p. 17/657.

25. Hugo Meltzl, «Vorläufuge aufgaben der vergleichende litteratur. I», p. 57.

26. Citat en Berczik, op. cit., p. 223. 
si bien Petöfi nos pertenece, la literatura extranjera puede igualmente pretender un derecho sobre él, y no basta con no frustrar este derecho, sino que tenemos que hacer todo lo posible para que Petöfi sea conocido en el mundo entero, como los otros espíritus de la humanidad que han escrito y sufrido por todos. ${ }^{27}$

Su lectura del poeta, así pues, conlleva una doble intervención sobre la constitución de la literatura nacional y de la literatura universal. En este sentido, Acta Comparationis Litterarum Universarum constituye la realización de estas convicciones: basta repasar sus índices para comprobar que, desde el primer número, son muy raras las entregas sin la pertinente sección «Petöfiana». Por otro lado, también de acuerdo con el precepto goethiano asumido como principio, la poesía -y especialmente la poesía popular- será el género mejor atendido, también en lo que respecta a las traducciones: en la portada aparecía siempre, perdida en el marasmo lingüísticotipográfico, la siguiente nota editorial: "Revue Polyglotte pour l'étude des littératures classiques et populaires de toutes les nations du monde. Chansons, contes, proverbes, légendes, superstitions, devinettes et autres traditions de tous les peuples. Articles dans toutes les langues du monde à l'aide de traductions littérales». ${ }^{28} \mathrm{La}$ traducción resulta, así pues, otro factor clave retomado de la propuesta goethiana, especialmente en lo que respecta a Petöfi.

En este sentido, hay que reconocer que Meltzl consigue plenamente su propósito: el primer año ya ha conseguido publicar traducciones de su poeta predilecto al francés, (a cargo de Frédéric Amiel), al inglés, sueco, islandés, italiano; y también, de la mano de Máinez, al castellano. En este sentido, no resulta descartable que, para Máinez, las traducciones de Petöfi tuviesen un valor más estratégico que literario: una especie de peaje necesario para conseguir la correspondiente reciprocidad de trato a Cervantes por parte de Meltzl.

Összehasonlitó Irodalomtörténelmi Lapok es el modelo que Máinez reconoce como paralelo al suyo, puesto que interpreta que lo que Meltzl propone con Petöfi no es sino la misma operación crítica que se había convertido casi en su cruzada personal: el cervantismo, en el que confluye una especie de substitución de la fe religiosa que Máinez había abandonado con la proclamación de la Gloria de Cervantes como exaltación filológica nacional de alcance universal:

Escribiendo Cervantes su poema, escribía mucho más que el poema escrupulosamente calcado en los ordinarios y sabidos preceptos, mucho más que el poema posible y aceptable en una literatura, o en una época determinada; (...) su obra tenía más alto fin que un poema cualquiera, porque su obra había de ser el gran poema de la humanidad, la gran epopeya donde se ven retratados, no esta ni aquella sociedad, sino todas las sociedades y todos los pueblos. ${ }^{29}$

Crónica de los Cervantistas se convierte en la plataforma de difusión local, nacional e incluso, al menos así lo pretendía, internacional de la Vida de Cervantes, tanto de la del autor del Quijote como del propio libro de Máinez.

27. Id. ibid., p. 222.

28. Acta Comparationis Litterarum Universarum, vol. III, n. 1-2, enero de 1888, p. 1

29. Ramón León Máinez: Vida de Cervantes, op. cit., p. 158. 
Por eso, su producción crítica se vuelve tan ubícua como repetitiva: de la misma manera que publica fragmentariamente en Crónica de los Cervantistas, (como también hará años más tarde, en El Pueblo) diversos fragmentos antes de publicarse en forma de libro, el "Comentario inédito de El Quijote» publicado en Összehasonlitó Irodalomtörténelmi Lapok no es sino un fragmento de los que acompañan su edición, concretamente del volumen tercero. Además, casi tan importante como sus propias publicaciones debe considerarse la recepción de ese cervantismo en las páginas de Összehasonlitó Irodalomtörténelmi Lapok. En junio de 1877 aparece una reseńa en alemán de la biografia de Cervantes y de la edición del Quijote, de Máinez, firmada por H. W. Wernekke bajo el título "¡Gloria a Cervantes!», en que se elogiaban tanto esas dos obras como la trayectoria y propósito de la revista, incluyendo un encomiástico comentario de uno de tantos artículos que, bajo el título «iGloria a Cervantes y a los cervantistas!», aparecía en la revista -en este caso, el artículo aludido era de Francisco Rodríguez Blanco. Y el mismo Hugo Wernekke firma, en marzo de 1878, «Die Mainez'sche Ausgabe des Don Quijote», en que además, se retomaban las argumentaciones tanto del propio Máinez como de James P. Baynes, que en octubre de 1877 reseñaba «Vida de Cervantes of Mainez» ${ }^{30}$. Haciéndose eco de estas publicaciones, Crónica de los Cervantistas publica una nota de agradecimiento en el último número del año 1878, que de hecho es uno de los pocos que aparece aquel año, en el mes de julio:

Damos las más expresivas gracias a los ilustrados críticos extranjeros James Baynes, del Museo británico (Londres), y Dr. H. Wernekke, profesor de la Escuela Industrial de Borna (Leipzig) por los artículos en que se han ocupado favorablemente de nuestros trabajos biográficos y críticos respecto de Cervantes. Tan docta análisis nos honra por extremo.

30. James P. Baynes, «Vida de Cervantes of Mainez», Összehasonlitó Irodalomtörténelmi Lapok, XV, 15 de noviembre de 1877, p. 316-317: «In this, the most complete account yet published of the life of Spain's greatest writer Don Ramon Máinez has earned the gratitude of all who know and love Don Quixote, that type of all that is noblest in the Spanish character. The main features of the life of Cervantes, his valiant services in Lepanto, his capture and his imprisionment in Algiers, the desperate hardihood with which he planned and wold have, but for treachery, effected his escape, with that of this companions in slavery, and his subsequent ransoming are all too well known to need comment; but the autor neglect wich awaited him on his return to Spain, and the persistent ill fortune wich pursued him to the day of his death will account for the strain of sadness through rarely of bitterness, wich pervades his works. As was to be expected from so distinguished a "Cervantista" as our Author we have a full analysis of the writings of his Memoir, but specially interesting are his comments upon those lesser works of Cervantes which have been overshadowed by the very greatness of the reputation of that inimitable book which towers before the world as the representative of Spanish literature. His Novelas Ejemplares, so little known and yet so deserving of study and admiration, his poems and even his comedies are all analysed with that loving minuteness without which no criticism can be satisfactory; and we rise from the perusal of Don Máinez's Memoir with the feeling that never before has the life of Cervantes been so worthily treated. The text of the Quixote is, os far as it has reached us, most carefully edited, though perhaps not so carefully printed as it deserves; and we look forward with interest to that amplification of the Author's theory that Avellaneda the spiteful continuer of the first part of Don Quixote, was but an alias for Lope de Vega». H. W. (Hugo Wernekke): «iGloria a Cervantes!», Összehasonlitó Irodalomtörténelmi Lapok, XI, 15-6-1877, pp. 227-228. Id.: «Die Mainez'sche Ausgabe des Don Quijote», XXV, 15 de marzo de 1878, 517-519. 
Asimismo enviamos nuestro más sincero reconocimiento al Sr. Meltzl, por la amabilidad con que se ha accedido a insertar em su importante periódico «Zeitschrift für Vergleichende Litteratur» los escritos de los dos literatos mencionados, examinando nuestras producciones cervantinas ${ }^{31}$.

Además, con su influencia, Máinez consigue que se publique en la revista transilvana el poema «Culto de amor a Cervantes», de Romualdo Álvarez Espino, en versión original y traducción alemana de Meltzl; cuya aparición es agradecida y celebrada en la sección de noticias varias de la revista gaditana:

Nuestro querido amigo el sabio profesor de la Universidad de Kolozsvár (Hungría), doctor Hugo de Meltzl, ha tenido la feliz idea de conmemorar el aniversario de la muerte de Cervantes, insertando en el número de su excelente periódico "Zeitschrift für Vergleichende Litteratur" (periódico de literatura comparada) correspondiente al día 15 de abril de este año, un bello soneto del Sr. Álvarez Espino, titulado "Gloria a Cervantes", con la traducción alemana hecha por el citado doctor Meltzl.

Tan delicado recuerdo hacia el príncipe de los ingenios españoles por parte del insigne profesor húngaro, es una prueba más de la admiración que profesa a nuestra literatura y a nuestro país, por lo cual le enviamos nuestros más sinceros agradecimientos como cervantista y como espańoles. ${ }^{32}$

Y, unos meses más tarde, en septiembre, un nuevo poema del mismo pedagogo krausista: «Un pensamiento a la memoria del fénix de los ingenios» -en esta ocasión dedicado a Lope de Vega,- traducido al alemán por el colaborador de Leipzig, el ya citado Hugo Wernekke ${ }^{33}$. No debe olvidarse que a Lope de Vega atribuye Máinez la autoría del Quijote de Avellaneda, bajo pseudónimo; por tanto, el poema no deja de ser, en el fondo, una nueva meditación cervantina.

El objetivo de Máinez está cumplido: la publicación de los sonetos de Álvarez Espino, acompañados de traducción alemana, culminaría la parte simbólica, poética, de la empresa, mientras que la doctrinal había quedado suficientemente cubierta por el mismo Máinez; las reseñas de sus trabajos daban finalmente a Cervantes -y a él mismo- la dimensión internacional buscada.

Así, como hemos visto, en el número de 30 de junio de 1877 se iniciaba una colaboración a la que solamente faltaba un detalle: el retorno de tal esfuerzo a los lectores espańoles en forma de reciprocidad entre Összehasonlitó Irodalomtörténelmi Lapok y Crónica de los Cervantistas. Era necesario que se refrendase, más allá de las notas de agradecimiento, esa internacionalidad

31. «Noticias varias», Crónica de los Cervantistas III, n. 2, 1878, 15 de julio de 1878, p. 79.

32. «Noticias varias», Crónica de los Cervantistas III, n. 2, 1878, 15 de julio de 1878, p. 78.

33. Romualdo Álvarez Espino, «Culto de amor a Cervantes», Összehasonlitó Irodalomtörténelmi Lapok, XXVII, 15 de abril de 1878, 550-551. Id. «Un pensamiento a la memoria del fénix de los ingenios», XXXIII, 15-9-1878, 72-73. Sobre Álvarez Espino, véase Alberto Romero Ferrer, 2001, «Romualdo Álvarez Espino. Un capítulo del pensamiento liberal gaditano», en Alberto Romero Ferrer y Fernando Durán (Eds.): Veinticinco escritores raros y olvidados, Cádiz, Servicio de Publicaciones de la Diputación, 2001. 
alcanzada por la figura de Cervantes, a través de la mirada extranjera. Ese momento culminante llega un ańo más tarde, el de 15 de julio de 1878, con la incorporación de Hugo von Meltzl como corresponsal en Austria-Hungría para que realice el balance de las aportaciones germánicas al cervantismo. Una primera -y única- colaboración de Hugo von Melztl en la revista gaditana, bajo el título «Literatura Cervántica en Alemania y en Austria Hungría», que, no puede perder el tono de agradecimiento:

Alentado y honrado por las instancias de mi apreciable amigo el Sr. D. Ramón León Máinez, y deseando expresar la admiración que siento por la hermosa literatura y majestuoso idioma de España, me he propuesto comunicar a la Crónica (bajo el título arriba expresado) observaciones sobre todo lo que encuentro digno de notar en la literatura Cervántica de Alemania y de Hungría.

Al hacer esto trataré no solamente de lo que puede llamarse novedades, sino también de la literatura antigua, no con orden riguroso, sino generalmente bajo el aspecto importante de la Bibliografía, y rara vez bajo el de la crítica estética.

Me ocuparé, no solamente de lo que tiene relación directa, sino también de lo que la tenga indirecta (lo cual para el investigador es frecuentemente de mucha más importancia, aunque la relación sea aparentemente muy ligera y distante. ${ }^{34}$

Y, efectivamente, lo que sigue es la reseña -seguramente en traducción del mismo Máinez- de un libro que tiene una «relación indirecta» con el autor del Quijote; solamente "contiene varias alusiones a Cervantes y el autor se declara uno de sus mayores admiradores»: se trata de La viuda infiel. Una novela china y sus excursiones por la literatura del mundo, de E. Grisebach, del cual más que realizar un comentario se extracta un pasaje -que bien podría considerarse heredero directo la célebre conversación entre Goethe y Eckermann el día 31 de enero de 1827- en el cual se reflexiona sobre Cervantes en los siguientes términos:

Resulta grandemente (dice) el contraste que ofrecen las obras del más eminente de los Poetas españoles.

Lo que falta al sencillo Boccacio, y también al ciertamente mucho más serio Antonio de la Sale, el profundo aprecio de la santidad del matrimonio y de los vínculos de la familia, el aprecio del valor eterno del estado por el cual, y en el cual, únicamente es posible la moralidad, esto se nota en cada página de Cervantes.

No es que él, que sabía tan a fondo lo que es la vida humana, con sus mil sendas tortuosas, la revestía con un idealismo falso; no es que daba a sus héroes la insípida gloria de una belleza y una moralidad abstractas: no, sus hombres son tomados de la vida real, y sus historias tienen el realismo casi acerbo que marca los más hermosos cuadros de la escuela holandesa.

La significación social de estos cuadros, la representación simbólica de las ideas por medio de ellos: he ahí el idealismo de Cervantes. (...) la totalidad de la poesía, este espejo del mundo, quiere, que al lado de Cervantes encuentren también Boccacio y la Sale su sitio de honor. Lo que hay de común en estos novelistas antiguos, existe también para

34. Hugo von Melztl, «Literatura Cervántica en Alemania y en Austria Hungría», Crónica de los Cervantistas III, n. 2, 1878, 15 de julio de 1878, p. 66-67. 
nuestra novela china: el mismo verdadero realismo artístico, hasta en los más pequeños detalles; el mismo estilo castizo y sencillo: con Cervantes, sin embargo, sólo tiene propiamente de común su aprecio por el valor de la familia y de la piedad, y el espíritu elevado que distingue la obra; pero por efecto del espíritu del bubdismo, (sic) parece todo abstracto y distinto de la vida real, mientras las novelas de Cervantes pertenecen entera y verdaderamente a esta vida, y solamente en El Quijote parece que se oye un eco, un suspiro que expresa la nulidad de todos los sufrimientos y regocijos humanos.

El bello escrito de Grisebach merecería ser traducido al hermoso idioma de Cervantes. ${ }^{35}$

Esta argumentación casi permite considerar como una reconvención la recomendación de Meltzl, ya que es obvio el contraste entre el tipo de reflexión que le interesa presentar a los lectores de Crónica de los Cervantistas con la falta de sentido de la crítica en los «Comentarios» de Máinez. La manera de enfocar la cuestión del realismo en Cervantes, que no es consecuencia de la devoción por el autor sino de su relectura en clave europea, permite la comparación con otros modelos de realismo novelístico -aunque sea en clave moral- europeos y chinos, e incluso establecer una posible comparación con el realismo pictórico. Nada de esto se corresponde con el proyecto cervantista de Máinez.

De todas maneras, ese momento de apogeo coincide con el ocaso del cervantismo apologético en sí: en la misma página en que aparece la nota de Meltzl concluye el artículo de Romualdo Álvarez Espino antes citado, «Un modo raro de entender las cosas», en el que se defiende a sí mismo y a la revista de las críticas vertidas por José Nakens, que desde las páginas de El Globo, en una artículo titulado «Los admiradores de Cervantes», llegó a parodiar-todo sea dicho, casi sin esfuerzo- los argumentos y características formales de Crónica de los cervantistas, señalando que bajo su cabecera se encuentra siempre «una lista de colaboradores que nunca escriben, y después los elogios y alabanzas que en prosa de distintos calibres y en variedad de metros disparan los redactores, cual si le fuera permitido al entusiasmo prescindir de toda regla literaria ${ }^{36}$; $y$, dando cuenta de la desmedida admiración por un enciclopedismo cervantino que raya no solamente en lo exagerado sino casi en lo sobrehumano, afirma que: «Si Cervantes describe las espuelas que usaba don Quijote, publican una serie de artículos, cuando no un libro, tratando de probar que era el mejor maestro armero de su época; si habla de zapatos, el mejor zapatero; si de montańas, el mejor geólogo, y así sucesivamente, sin advertir que si Cervantes hubiera sido todo cuanto ellos pretenden, a buen seguro que escribiera el Quijote» ${ }^{37}$, lo cual no es sino una reprimenda a las afirmaciones de Máinez sobre la «portentosa suma de erudición que revela en aquel gran escritor, quien con sus magistrales y profundos conocimientos y suficiencia trata de gobiernos, estados, religión, leyes, naciones, guerras, historia, geografía, astronomía, literatura, ciencias,

35. Ibidem.

36. José Nakens, «Los admiradores de Cervantes», El Globo, Madrid, segunda época, núm. 493, jueves 15 de febrero de 1877 , p. 1 . Todas las citas del artículo de Nakens tienen la misma referencia.

37. Romualdo Álvarez Espino, «Un modo raro de entender las cosas», art. cit., p. 64. 
artes, agricultura, comercio, industria, en fin, de todo y sobre todo ${ }^{38}$. Ciertamente, tales afirmaciones no solamente son una exageración, sino una prueba de lo extraliterarias que llegan a ser estas consideraciones, no solamente por el hecho que no dejarían tiempo ni fuerzas para poder emprender la obra literaria, sino porque precisamente la novela articula y rearticula, desde su mirada específicamente literaria, todos los saberes que requiera la narración sin pretensión enciclopédica alguna. Espino insiste en que:

Diga el Sr. Nakens, y pruebe, que no resulta más gloria para Cervantes con suponerle exageradamente "geógrafo, historiador, náutico, agricultor y culinario» por más que todos esos conocimientos y otros muchos de filosofía, moral, política, literatura y ciencias sociales se necesitan para escribir un libro que simboliza un siglo y habla con la humanidad, que inmortaliza a un hombre y glorifica a un pueblo, y que tiene por vida la eternidad y por admirador al género humano.

Con esta argumentación solamente consigue darle la razón a su adversario, puesto que una cosa es la crítica literaria, y otra muy distinta los procesos de canonización literaria -lo que en Crónica de los Cervantistas se denomina y reclama repetidamente como «Gloria a Cervantes». Estos procesos, y no la crítica o la historia literaria, son los que ocupan la revista de Máinez, olvidando que en realidad, sin una sólida crítica literaria, los procesos de institucionalización pecan de falta de fundamento, y los monumentos así construidos resultan tan fáciles de derruir como de levantar.

Así pues, la deriva apologética del cervantismo tuvo respuesta explícita, simultánea y polémica, junto a otras respuestas y debates implícitos o menos directos, no por ello menos importantes, como la aportada por José María de Pereda en Esbozos y rasguños, subrayada por Durán ${ }^{39}$. Nakens, haciendo volver el debate a los términos literarios, afirma que el principal problema de estas iniciativas, sociedades y revistas es que olvida elogiar a Cervantes imitándolo, es decir, que se libran a un entusiasmo tan inconsciente como aquejado de falta de talento. Sus conclusiones son demoledoras para los propósitos de Máinez y su círculo:

\footnotetext{
Admiremos y elogiemos al genio que nos honra, pero no de manera que los profanos lleguen a dudar del mérito de un autor que inspira cierta clase de escritos; que todo cuanto dediquemos a su memoria sea digno de él; que pocos, muy pocos, se crean autorizados para escarbar los cimientos del pedestal de su gloria, buscando allí un hueco donde colocarse y de este modo formar un monumento parte de aquel conjunto inmortal; y que todos, en fin, contribuyamos a evitarle disgustos literarios, si, como afirma el espiritismo, puede oír desde otros planetas los cantos que entonan en alabanza suya sus admiradores de oficio.
}

La respuesta de Espino, sin embargo, no viene sino a confirmar mucho de lo que Nakens afirmaba, ańadiendo además el matiz patriótico en el que se confunde una crítica severa a una manera de entender el cervantismo y la crítica literaria con un ataque a España misma: «No era esta la ocasión de lanzar

38. Ramón León Máinez, Vida de Cervantes, op. cit., vol. I., p. 208-209.

39. Fernando Durán López, art. cit., p. 30 
dardos contra nuestra patria, acusándola de ingrata, ni de debilitar los esfuerzos que hoy hace por vindicar la memoria de su infortunado hijo» ${ }^{40}$, afirma.

Poco después la revista deja de publicarse, en medio de una polémica sobre el modelo de reivindicación de la obra de Miguel de Cervantes, y se extingue no solamente el intercambio entre ambas publicaciones, sino también la colaboración de Máinez en Összehasonlitó Irodalomtörténelmi Lapok, sin llegar a hacerlo bajo la cabecera Acta Comparationis Litterarum Universarum. Queda, así pues, también en el terreno de lo conjetural cómo habría podido evolucionar la relación entre ambos, a la vista de las profundas diferencias entre sus discursos.

Todo ello da la medida de la importancia de este episodio, que no es menor, aunque sí relativa. La relación entre Ramón León Máinez y Hugo von Meltzl de Lomnitz resulta mucho menos significativa que el contraste entre Crónica de los Cervantistas y Acta Comparationis Litterarum Universarum. El precio de recordar este episodio quizá sea favorecer un grave error de apreciación: considerar que esta relación pueda convertir a Máinez en un precursor de la Literatura Comparada en España, a través de Cádiz. No: un introductor no es necesariamente un precedente, ni un precursor. A evitar ese posible malentendido, de un género nada infrecuente en las Historias de la Literatura Comparada, aspiraban estas páginas. Pero también a recordar que la Historia de la Literatura Comparada está llena de contradicciones, paradojas, momentos ejemplares y entremeses irrisorios, héroes y antihéroes. De todo ello, como también Europa, también está hecha la literatura misma.

40. Romualdo Álvarez Espino, «Un modo raro de entender las cosas», art. cit., p. 64. 


\section{Apéndice documental}

\section{I}

\section{Ramón León Máinez en Acta Comparationis Litterarum Universarum}

Comentario inédito del Quijote, I

Összehasonlitó Irodalomtörténelmi Lapok, X, 31 de mayo de 1877; pp. 185-188 (la numeración se corresponde a 2 columnas por página.)

En los capítulos XXIV al XXVII de Don Quijote de la Mancha, se ofrece mucha y muy grande enseñanza en medio de la aparente festividad del relato. La aventura de Sierra Morena, la penitencia que hace allí Don Quijote, y los extrańos sucesos que de ella se siguen, tienen una significación muy grandiosa, y una filosofía admirable debajo de una ingeniosa perspectiva, en que debemos fijarnos para presentar a la vista de todos sus perfecciones, hasta ahor ocultas o desconocidas.

Don Quijote, siguiendo siempre en pos del bello ideal que se había forjado en su imaginación, prendado de aquella hermosura encantadora, creación de su mente alta y generosa, de Dulcinea, personificación de la verdad, de la justicia, de la rectitud y de la perfección más grande, se sacrifica por todas las buenas causas, demuestra siempre su magnanimidad y su alteza de carácter, combate por todo lo que cree noble y digno, aún en medio de sus equivocaciones es respetable, y lleva su entusiasmo por la dama que simbolizaba sus sublimes principios hasta separarse por completo de la lucha social, donde sólo hallaba desprecios, reveses, compasión, desdenes, ingratitudes, injusticias, y retírase de toda comunicación humana para fortalecerse con la soledad en sus propósitos, para demandar nuevos auxilios a quien le inspiraba tan majestuosos pensamientos, y poder triunfar con más buen suceso desde entonces contra las maquinaciones del mal y contra las falsedades de una sociedad corrompida y metalizada, a la que en vano trataba de regenerar el nunca bien elogiado caballero.

Sancho Panza, personificación en estos capítulos del más sórdido interés y del más grosero egoísmo, se burla al principio de los proyectos del hidalgo, ni más ni menos que hicieron luego el barbero Maese Nicolás y el cura Pedro Pérez, demostrándose así de un modo acabadísimo y admirable, que lo mismo la clase pobre, que la media, que la ilustrada, no saben apreciar casi nunca los pensamientos excelsos, ni estimar las tendencias regeneradoras, ni respetar y favorecer a los hombres que, arrostrando peligros, ridículos y dificultades, pelean denodadamente por el triunfo de la verdad y del pundonor, de la rectitud y de la sinceridad, sin temor que les conturbe, ni desaliento que les abata.

Tal modo de proceder por parte de los pocos hombres que saben sacrificarse por la sociedad, es para el vulgo ignorante y aún para el vulgo ilustrado también, acciones descabelladas, intentos desvariados, extravagancias y locuras dignas de risa o de compasión. Importa poco que quienes abrigan pensamientos regeneradores encarezcan la importancia de sus doctrinas, la [n]obleza de sus actos y la rectitud de sus intenciones: aquellas mismas defensas de una buena causa se conceptúan como nuevas manifestaciones de enajenación, y la burla, el sarcasmo, la falsedad, el egoismo y la soberbia sig[u]en imperando, y se menosprecia y humilla a los que con sublime entereza piden la regeneración de las sociedades, y hablan sin temor a nada el lenguaje de la verdad, como si los pueblos no pudiesen vivir sino entre los aires corrompidos de la adulación, de la mentira y de la servil lisonja.

Pero el hombre íntegro, generoso, todo abnegación por sus semejantes, de quien es representación fidelísima Don Quijote, jamás se intimida antes las maquinaciones del mundo positivista: en esa lucha gigantesca que tiene que sostener contra las malas artes de todos, podrá quedar vencido, y quédalo efectivamente a la continua; mas al fin se le hace justicia, se reconocen 
sus altos designios, se subliman sus actos, y se circuye su nombre con la aureola de la gloria, en tanto nadies se acuerda, sino para compadecerlos, de cuantos se opusieron al trinfo de sus ideas y a la realización de sus propósitos generosos.

Ramón León Máinez

Cádiz, 11 de mayo

Comentario inédito del Quijote, II

Öszehasonlitó Irodalomtörténelmi Lapok, n. XII, 31 de junio de 1877; pp. 233-236.

La historia amorosa de Cardenio y Luscinda con la perfidia y falsa amistad de Don Fernando y desventuras de Dorotea es uno de los más bellos episodios que introdujo Cervantes en su admirable obra, y a la vez que la presta ma[y]or vida, variedad y animación con ellos, ofrece una enseñanza saludable y un ejemplo moral muy provechoso.

Propúsose Cervantes describir los funestos resultados, las perturbaciones, las desdichas que produce la depravada conducta de un joven licen[c]ioso e irreflexivo, y consíguelo cumplidamente relatándonos los procederes, por lo general detestables, de Don Fernando. Falso siempre, así se burla de la verdadera amistad que Cardenio le profesaba, como del recato de la desgraciada Dorotea, quien pierde su honra y su felicidad dando oídos a sus palabras engañadoras. Entregado Don Fernando al vicio, nada le detiene en el camino de las imprudencias, y ni la amistad ni el pudor, ni el respeto a su familia, le retraen de poner por obra sus licenciosos pensamientos. Pero al efectuarlos aquel joven, sin miramientos ni consideraciones a nada ¡cuántos males causa, cuántos desasosiegos introduce, cuántos disgustos ocasiona, y cuántas penalidades y perturbaciones y zozobras!

Dorotea, aquella joven tan hermosa, y tan feliz hasta entonces, abandona su morada, huye de su pueblo, su deshonra se hace pública, y su conducta llena de sufrimiento y dolor los corazones de sus atribulados y antes tan venturosos padres. Cardenio queda indignado y suspenso al conocer tanta falsedad y tanta depravación en su antiguo amigo, ve desvanecidas todas sus esperanzas nobilísimas, siente todo lo horrible de su situación cuando presencia el no pensado casamiento de su falso amigo con su adorada Luscinda, y agitado por los celos, por el odio, por la desesperación, huye de la sociedad, y, perdido el juicio, vive del modo más deplorable y mísero en las asperezas de sitios agrestes, y alejado de toda comunicación humana. Luscinda, que tan entrañablemente amaba a Cardenio, vese obligada a dar su mano a Don Fernando, que era a quien sus padres tenían en mayor estima por la riqueza y nombre de su familia, y sufre indeciblemente viéndose forzada en su voluntad, contrariada, en sus deseos, y al fin sacrificada a la tiránica determinación de los autores de sus días. Y por último, los padres mismos de Luscinda, ¡cuánto no sufren después del malhadado desposorio de su hija con Don Fernando, tornándose todas las esperadas alegrías en presentes lloros, sobresaltos y congojas.

¡Cuán funestos resultados los de la licenciosa conducta de un joven calavera, de un falso amigo, de una persona entregada por completo a la mentira i al vicio como Don Fernando! ¡Y cuán perfectamente los presenta Cervantes en el relato referido para enseñanza y para ejemplo!

Noble y generoso en todo Cervantes, deseoso siempre de ofrecer la reparación después del mal, nos presentaráen sucesivos capítulos un desenlace ingenioso y feliz de los acontecimientos que forman este drama de amor en que actúan Don Fernando y Dorotea. Cardenio y Luscinda; pero ampliamente deja antes demostrado que, para llegar a ese resultado satisfactorio, rarísimo en casos como el presente, hay que pasar por muchas expiaciones, desventuras y peligros, y que sólo en la práctica de las buenas acciones, de los nobles actos, de la verdad, de la rectitud, de la leal correspondencia amistosa, y del pundonor y desinteréspueden hallar su reposo y su ventura las sociedades y las familias.

Ramón León Máinez

Càdiz: Mayo de 1876 
«Petöfiana, II. Petöfi in spanischer Sprache»

Öszehasonlitó Irodalomtörténelmi Lapok, xIII, 15 de setembre de 1877; p. 273-274.

Don Ramón León Máinez schreibt uns aus Spanien vom 3. August d. J., indem er uns die unseres Wissens:

Dedico todas las noches bastante tiempo a la traducción de las poesías del gran vate húngaro Petöfi, por V. traducidas en idioma alemán. El resultado de mi trabajo es altamente grato para mi corazón. Mientras más se estudian las poesías del poeta eminente de su país de V., más se acrecienta la admiración hacia su nombre preclaro y la veneración hacia su memoria. ¡Qué sencillez, qué dulzura, qué encanto, que deleitosa hermosura en todo! ¡Todo es sentimiento, alma, vida en las poesías de Petöfi! La verdadera inspiración les anima; los cuadros que presenta siempre admiran por su fidelidad y su belleza; ni un pensamiento hay superfluo, ni una palabra de más. -Como muestra de mis trabajos copio aquí la traducción que tengo hecha de la breve, pero sentidísima poesia titulada "A dal" (Das Lied)

\section{La Canción}

Cuando el pequeño infante,

Desvelado y llorando está en su cuna

Solícita y amante

La nodriza, canción canta oportuna,

Con que ve conseguido

Que presto el niño quede adormecido.

Así contigo pasa,

Mi congojado corazón sombrío:

Cuando llan[t]o sin tasa

Viertes, desvelado estás, bien mío,

Yo ofrezco a tus pesares

Breve tranquilidad con mis cantares.

Ahora estoy ocupado con la versión y composición en verso castellano de la magnífica inspiración titulada: $A z$ árveleány (Das verwaiste Mädchen) La huérfana. ...donde compiten los pensamientos sublimes[,] los tiernos sentimientos y las más patéticas pinturas con la expresión más sencilla y las frases más llanas y dulces. ${ }^{41}$

La Huérfana

(Traducción castellana de la poesía de A. Petöfi, titulada $A z$ árveleány (Das verwaiste Mädchen))

Összehasonlitó Irodalomtörténelmi Lapok, n. XII, 15 de octubre de 1877; p. 321-324.

Un ser tan solamente

Ayer más en el mundo ¡ay! existía;

Y hoy, mi pobre mente,

Conturbada y sombría,

Extinguida la tierra ve, y vacía.

¡Ya mi madre no existe!

¡Ay, ya descansa en sepulcro frío;

41. Se ha actualizado la ortografía, y se ha corregido un evidente error de transcripción: «llan'o ain tasa». 
En mi alma, en mi albedrío,

Sobre tu tumba pongo, oh Amor mío!

Ay madre, madre mía,

¿Por qué también mi vida no llevaste

Contigo, mi alegría,

Si ya me arrebataste

Todo el placer y mi ánimo acuitaste?

Mi sol, madre, tu fuiste,

Y yo tu rayo fuí: ¿̨cómo insepulta

Dejarme tú pudiste?

Cuando Febo se oculta,

No él sólo, con sus rayos sepulta.

Pero ¿por qué incesante

Mi voz de pena honda y de gemidos

Levanto querellante?

¿Acaso mis quejidos

De ti, madre del alma, son oídos?

Sobre la sepultura

Que te encubre y encierra, madre amada,

Es tu hija sin ventura;

Y tú, de ella alejada,

Más que la tierra más lejos situada.

Con sollozos herida,

Al verte ya en el féretro encerrada,

Tu hija dolorida,

Con la voz levantada,

"Despierta, -decía- madre, oh madre amada!"

¿En el día postrero

Despertarás tú, madre, por ventura,

Del sueño duradero,

Si a mi clamor, que aún dura,

No has despertado, ni ante mi amargura?

¡Oh noche de dolores

Junto al lecho de la madre doliente!

La luz sus resplandores

Da opaca y falleciente.

¡Extinguirse tu vida así se siente!

En la pobre vivienda

Solitarios estábamos velando,

Cuando la Parca horrenda,

Su torva faz mostrando,

Odio, furor, creuldad viene sembrando. 
Y con su dedo helado

El corazón de la madre querido

Velozmente ha tocado;

quedando al punto herido,

Inmóvil, yerto, sin ningún latido.

Y cuando el triste caso

Es ya llegado de su horrible muerte

Me inclino en su regazo:

Así el Otoño inerte

En árbol caído su neblina vierte.

Con besos yo deseo

Mi vida transmitirte, bien amado;

Mas, jay! con dolor veo

Que, mi anhelo tocado,

Tu vida, al expirar, en mi has dejado.

III

Flores, lozanas flores

En tu tumba pondré yo cada día.

No rocíos bienhechores

Daránlas lozanía:

¡Las regará mi llanto, madre mía!

Aquello que adorado

Por la madre de mi alma fue en su vida,

Eso por mi es amado:

Con guirnalda tejida

De flores orno su tumba querida.

Las flores ella amaba:

Aún en mi oido las palabras suenan

Con que así lo expresaba.

¡Recuerdos que resuenan

Siempre en mi pecho a quien las penas llenan!

Mi madre bien amada

-“Quiero flores, hija, me decía;

Qué alma muy malvada

Aquél alma sería

Que de la flor no amase su alegría”

"Bondad de ánimo y flores

Hermanas son gemelas ciertamente,

Sábelo, mis amores:

Las dos constantemente

Al corazón rodean noble y clemente."

¿La flor es otra cosa

Que de la tierra la bondad preciada? 
Y la dulzura hermosa

Del corazón, y amada,

¿No es del alma la flor más regalada?

En la tumba reciente

Tuya, oh madre, coloco frescas flores:

Desde el cielo riente,

Tus ojos seductores

¿No fijas ora en ellas, sol de amores?

¿No ves tu sepultura

Con profusas guirnaldas adornada?

Y mustia de tristura,

¿No ves a tu hija amada

Caer ya de pesares agobiada?

Cádiz: 1877

Ramón León Máinez

Ramón León Máinez: «Los idiomas de América Latina»

Los idiomas de América Latina. Estudios biográfico-bibliográficos por D. Félix C. y Sobrón, médico-cirujano e individuo de varias Sociedades científicas. Madrid, Imprenta a cargo de Víctor Sáis, calle de la Colegiata, $n^{\circ} 6 ., 238$ pág. $8^{\circ}$.

Összehasonlitó Irodalomtörténelmi Lapok, n. XVII, 15 de noviembre de 1877; pp. 355-356.

Tiene por objeto este libro dar conocimiento de los más notables idiomas y dialectos que se hablaban y se hablan entre los indígenas de las diversas comarcas de América latina. Después de dar el autor una breve idea de la índole y mérito de los idiomas mejicano, chileno, peruano, paraguayo, brasileño, etcétera, y asimismo de los más notables dialectos acerca de los misioneros españoles y portugueses que, desde los primeros momentos de la conquista hasta nuestros días, han puesto mayores desvelos para civilizar a los indígenas, y estudiado con mayor esmero sus lenguajes y dialectos, costumbres, usos y tendencias. Las noticias bibliográficas que suministra el autor, dando cuenta de las gramáticas, diccionarios, métodos y otros libros análogos escritos por españoles en aquellos idiomas y dialectos, son muy curiosas, y servirán para despertar la afición a estos estudios en la Península, a la que tanto interesa todo cuanto se refiere a los países por ella descubiertos y civilizados en otros siglos. Da tambén noticias sobre los idiomas y dialéctos del Archipiélago filipino, y sobre el lenguaje de las Islas de Vavao. En suma, el trabajo del Sr. Sobrón es interesante como tratado biográfico-bibliográfico pues de los que han escrito, estudiado y propagado los idiomas de la América latina; pero demasiado breve en lo relativo a la índole, estructura e importancia de cada una de las lenguas de que se habla. El Sr. Sobrón, que demuestra erudición en esta materia, puede toda dar la perfección deseable a su trabajo con sólo hacer un libro más extenso.

Pero cualquier defecto que pueda notarse en el recomendable estudio del Sr. Sobrón, queda disculpado ante los nobles propósitos que le han animado a escribir página 132.

Cádiz

R. L. M. 


\section{II}

\section{Romualdo Álvarez Espino en Acta Comparationis Litterarum Universarum}

Romualdo Álvarez Espino: «Culto de amor a Cervantes» Összehasonlitó Irodalomtörténelmi Lapok, XXVII, 15 de abril de 1878; 550-551.

No ricas perlas de envidiable encanto

Vengo a encastrar en tu inmortal corona:

Dejo tan bello don a quien abona

Del genio y del saber el fuego santo.

Una flor nada más, húmeda en llanto

Que el pesar y el amor tierna pregona,

En la ofrenda, Miguel, que te abandona

Quien recuerda tu gloria y tu quebranto.

Yo esta adelfa arranqué de la orilla

Del triste Henares, donde en dias felices

Tú tal vez cultivaste su semilla,

Sabiendo cómo amargan sus raíces:

Viva está; más la dejo que sucumba,

Herida del dolor, sobre tu tumba.

Cádiz 1878 Romualdo Álvarez Espino

Romualdo Álvarez Espino: «Un pensamiento a la memoria del Fénix de los Ingenios» Összehasonlitó Irodalomtörténelmi Lapok, XXXIII, 15-9-1878, 72-73.

Sólo un rayo del cielo que ilumina

El fondo oscuro de la mente humana

Basta a dar la potencia soberana

Que hace el alma nacer siendo divina.

Con tu luz el espíritu fascina

De la absorta humanidad, que en ansia vana,

Ante una creación y otra, se afana

Por gozar de su gracia peregrina.

Y ella imita de Dios el don fecundo

Y sus obras espléndidas reparte

Para eterna enseñanza por el mundo

Donde se ostenta la virtud del arte,

Así desde la altura a España llega,

Con su genio inmortal, Lope de Vega.

Cádiz 1878

Romualdo Álvarez Espino 


\title{
III
}

\section{Hugo von Meltzl en Crónica de los Cervantistas.}

\author{
Hugo von Meltzl: «Literatura Cervántica en Alemania y en Austria Hungría», \\ Crónica de los Cervantistas III, n. 2, 1878, 15 de julio de 1878.
}

Alentado y honrado por las instancias de mi apreciable amigo el Sr. D. Ramón León Máinez, y deseando expresar la admiración que siento por la hermosa literatura y majestuoso idioma de España, me he propuesto comunicar a la Crónica (bajo el título arriba expresado) observaciones sobre todo lo que encuentro digno de notar en la literatura Cervántica de Alemania y de Hungría.

Al hacer esto trataré no solamente de lo que puede llamarse novedades, sino también de la literatura antigua, no con orden riguroso, sino generalmente bajo el aspecto importante de la Bibliografía, y rara vez bajo el de la crítica estética.

Me ocuparé, no solamente de lo que tiene relación directa, sino también de lo que la tenga indirecta (lo cual para el investigador es frecuentemente de mucha más importancia[)], aunque la relación sea aparentemente muy ligera y distante.

Doy, pues, principio por una producción notable, que tiene relación directa.

Grisebach, E. -La viuda infiel. Una novela china, y sus excursiones por la literatura del mundo. (3a edición: Stuttgart, Kröner, 1877, 12º, 128.

El ingenioso autor de esta hermosísima obra, una de las más antiguas, más conocidas y más apreciadas novelas, es conocido en el Parnaso alemán por el nombre de Heineahner, a quien el destino fatal ha forzado a ser tan exactamente semejante a su predecesor, que tiene hasta las mismas dolencias físicas (Como nuestro amigo Cassone de Sicilia) ${ }^{42}$.

La obra, que está publicada de un modo lujoso, contiene varias alusiones a Cervantes, y el autor se declara uno de sus mayores admiradores.

En los siguientes renglones damos el párrafo principal, que tal vez será considerado digno de inserción en las columnas de la CRÓNICA.

El autor habla, entre otras cosas, de la "novela moral" y observa que el ideal del matrimonio no es tan altop entre los pueblos romanos como entre los germánicos, puesto que entre estos últimos todavía domina el concepto antiguo que de ello tenían los Bubdistas, si bien no con toda la rigidez de las costumbres indias.

Cervantes sin embargo es una excepción notable entre los autores de la escuela romana. Pero dejemos hablar al autor:

«Resalta grandemente (dice) el contraste que ofrecen las obras del más eminente de los Poetas españoles.

Lo que falta al sencillo Boccacio, y también al ciertamente mucho más serio Antonio de la Sale, el profundo aprecio de la santidad del matrimonio y de los vínculos de la familia, el aprecio del valor eterno del estado por el cual, y en el cual, únicamente es posible la moralidad, esto se nota en cada página de Cervantes.

No es que él, que sabía tan a fondo lo que es la vida humana, con sus mil sendas tortuosas, la revestía con un idealismo falso; no es que daba a sus héroes la insípida gloria de una belleza y una moralidad abstractas: no, sus hombres son tomados de la vida real, y sus historias tienen el realismo casi acerbo que marca los más hermosos cuadros de la escuela holandesa.

42. Giuseppe Cassone, docto italiano, agobiado por una enfermedad cruelísima, ha traducido bellamente al italiano muchas poesías líricas del gran poeta alemán Heine. ( $\mathrm{N}$ de la $\mathrm{R}$.) 
La significación social de estos cuadros, la representación simbólica de las ideas por medio de ellos: he ahí el idealismo de Cervantes.

Antonio de la Sale en las "XV Joies" dibujaba con mano diestra y atrevida las sombras del matrimonio, tal como él lo había encontrado entre sus paisanos: él escribió un "martirilogio" de los casados.

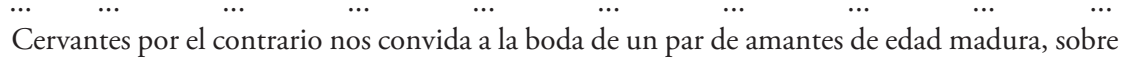
quienes extiende sus rayos el sol de una verdadera y permanente dicha matrimonial. Parece que, después de haber pasado las cascadas y torbellinos de las pasiones de la juventud, flota ahora sobre una corriente clara y tranquila. Su elevada moralidad parece no saber nada de los sufrimientos que en las novelas de Antonio de la Sale empiezan al acabar la ceremonia del matrimonio. O más bien, él los sabía perfectamente, pero sabía asimismo que hay en el mundo matrimonios verdaderamente felices, y su deseo era el dibujar estos solamente, para con tan suave persuasión llevar a sus paisanos por el mismo camino. Que esta era su intención, lo dice como el novelista chino, claramente en el prólogo de las "Novelas Ejemplares".

Pero la totalidad de la poesía, este espejo del mundo, quiere, que al lado de Cervantes encuentren también Boccacio y la Sale su sitio de honor. Lo que hay de común en estos novelistas antiguos, existe también para nuestra novela china: el mismo verdadero realismo artístico, hasta en los más pequeños detalles; el mismo estilo castizo y sencillo: con Cervantes, sin embargo, sólo tiene propiamente de común su aprecio por el valor de la familia y de la piedad, y el espíritu elevado que distingue la obra; pero por efecto del espíritu del bubdismo, parece todo abstracto y distinto de la vida real, mientras las novelas de Cervantes pertenecen entera y verdaderamente a esta vida, y solamente en El Quijote parece que se oye un eco, un suspiro que expresa la nulidad de todos los sufrimientos y regocijos humanos."

El bello escrito de Grisebach merecería ser traducido al hermoso idioma de Cervantes.

Dr. Hugo de Meltzl

Catedrático de la Universidad de Koloszvar (Hungría).

Bistritz (Siebenbürgen), 1878. 